\title{
Analiza i praktyczne ujęcie metodologii i mechanizmu dokonywania waloryzacji na przykładzie ustalonego i niewypłaconego odszkodowania za wywłaszczoną nieruchomość
}

\section{Wprowadzenie}

Rozprawy na temat procesu waloryzacji odszkodowania za wywłaszczoną nieruchomość ${ }^{1}$ zawężano niejednokrotnie do problematyki związanej z formą jej dokonywania, tj. decyzją administracyjną bądź czynnością faktyczna, techniczno-obrachunkową. Obecnie słusznie przeważa pogląd, że właściwą postacią jest forma decyzji administracyjnej, bowiem "[u]stalenie odszkodowania następuje w formie decyzji administracyjnej, waloryzacja, która jest uaktualnieniem przyjętej wysokości odszkodowania, wymaga zachowania tej samej formy - formy decyzji administracyjnej"2 $^{2}$. Niejednokrotnie problem waloryzacji wiąże się z kwestią ustalenia charakteru prawnego roszczenia o odsetki wynikające ze zwłoki lub opóźnienia w zapłacie odszkodowania za wywłaszczoną nieruchomość. Najbardziej przekonujące jest stanowisko, zgodnie z którym "[o]bowiązek zapłaty odsetek jest pochodny od obowiązku zapłaty sumy głównej. Skoro zatem obowiązek zapłaty odszkodowania powstał na tle

${ }^{1}$ Zagadnienie objęte dyspozycją art. 132 ust. 3 oraz ust. 2 w zw. z art. 5 Ustawy z dnia 21 VIII 1997 r. o gospodarce nieruchomościami (tekst jedn. Dz.U. 2018, poz. 121 ze zm.), dalej „u.g.n.” lub „ustawa o gospodarce nieruchomościami”.

${ }^{2}$ Wyrok Naczelnego Sądu Administracyjnego (NSA) w Warszawie z 17 XI 2010 r., sygn. I OSK 103/10, http://orzeczenia.nsa.gov.pl/cbo/query (dostęp: 9 XI 2018). Por. wyrok NSA z 14 XII 2012 r., sygn. I OSK 1460/11, http://orzeczenia.nsa.gov.pl/cbo/query (dostęp: 9 XI 2018); wyrok NSA z 30 XI 2012 r., sygn. I OSK 1297/11, http://orzeczenia. nsa.gov.pl/cbo/query (dostęp: 9 XI 2018). 
stosunku administracyjnego, to również obowiązek zapłaty odsetek od tego odszkodowania zachowuje administracyjny charakter"3.

Wobec powyższego można stwierdzić, że to właśnie droga administracyjnego postępowania zakończonego wydaniem decyzji jest jedynym i właściwym wyborem, jeśli chodzi o waloryzację odszkodowania za wywłaszczoną nieruchomość.

Na przestrzeni lat można zauważyć natomiast niepokojące zjawisko dowolności i niekonsekwencji w ujmowaniu zagadnienia, którym jest mechanizm waloryzacji kwot ustalonego, ale niewypłaconego odszkodowania za wywłaszczoną nieruchomość, a co za tym idzie, często niewłaściwe praktyczno-matematyczne przeprowadzanie przez organy administracji publicznej omawianej waloryzacji, których to organów tok myślenia powielają następnie sądy administracyjne. Wynikać to może nie tyle z niezrozumienia tematu, co niedostatecznej praktycznej wiedzy w zakresie sposobu, w jaki należy prawidłowo dokonać matematycznych obliczeń. Brak niewątpliwie ujednoliconych wytycznych, które wskazywałyby organom i sądom, jak prawidłowo przedmiotowe operacje matematyczne przeprowadzać. Trzeba pamiętać, że błędnie dokonana waloryzacja rzutuje na końcowy wynik, którym jest ustalona kwota odszkodowania, a także implikuje ważkie konsekwencje finansowe, mogące spowodować nienależne spełnienie świadczenia zapłaty odszkodowania zarówno po stronie organów państwa, jak i po stronie osób uprawnionych do zwrotu wywłaszczonych nieruchomości, zobowiązując je w ramach rozliczeń do zwrotu zwaloryzowanego odszkodowania.

Celem niniejszego artykułu nie jest krytyka funkcjonalności, czy też ocena poprawności i zgodności z prawem obecnego kształtu treści przepisu art. 5 u.g.n. ${ }^{4}$ Przepis ten, co prawda w brzmieniu sprzed

${ }^{3}$ Wyrok NSA z 15 III 2006 r., sygn. I OSK 525/05, http://orzeczenia.nsa.gov.pl/cbo/ query (dostęp: 9 XI 2018); wyrok Wojewódzkiego Sądu Administracyjnego (WSA) w Poznaniu z 15 IX 2010 r., sygn. IV SA/Po 406/10, http://orzeczenia.nsa.gov.pl/cbo/query (dostęp: 9 XI 2018).

${ }^{4}$ Zgodnie z art. 5 ust. 1. u.g.n. „[w]aloryzacji kwot należnych z tytułów określonych w ustawie dokonuje się przy zastosowaniu wskaźników zmian cen nieruchomości dla nieruchomości sklasyfikowanych w rejestrze cen i wartości nieruchomości, z uwzględnieniem danych wynikających z ewidencji gruntów i budynków.

Ust. 2. Prezes Głównego Urzędu Statystycznego ogłasza, w formie obwieszczenia, w Dzienniku Urzędowym Rzeczypospolitej Polskiej «Monitor Polski», wskaźniki zmian cen nieruchomości dla danego rodzaju nieruchomości, nie później niż w terminie 4 miesięcy od zakończenia kwartału, którego te wskaźniki dotycza, z podziałem na województwa.

Ust. 4. W przypadku gdy dla danego rodzaju nieruchomości nie ogłoszono nigdy wskaźnika zmian cen nieruchomości, waloryzacji kwot należnych z tytułów określonych 
nowelizacji ${ }^{5}$, był przedmiotem oceny zawartej w wyroku Trybunału Konstytucyjnego (TK) z 21 lipca 2011 r. ${ }^{6}$, którym uznano jego zgodność z Konstytucja, stwierdzając między innymi, że „niewykonanie obowiązku ogłaszania wskaźników zmian cen nieruchomości przez Prezesa GUS [Głównego Urzędu Statystycznego] nie jest wynikiem naruszenia zasad poprawnej legislacji, lecz zaniedbań tego organu"7.

Obowiązująca, bardziej precyzyjna treść art. 5 u.g.n., choć z pewnością nie jest doskonała pod wieloma względami, stanowi jednak znaczący krok naprzód w spełnieniu pokładanych w nim oczekiwań. Niewątpliwie słusznym posunięciem prawodawcy było przeniesienie treści nieobowiązującego już art. 227 u.g.n. do ust. 4 wyżej wymienionego przepisu art. 5 u.g.n. ${ }^{8}$ Należy brać pod uwagę, że gdyby art. 227 u.g.n. został wyeliminowany z ustawy o gospodarce nieruchomościami, nastąpiłaby sytuacja trudna, przy braku ogłoszenia wskaźników zmian cen nieruchomości nie byłoby bowiem alternatywnej drogi przeprowadzania waloryzacji kwot określonych w wyżej wskazanej ustawie, przewidzianej w postaci zastępczego kryterium, jakim są wskaźniki cen towarów i usług konsumpcyjnych ${ }^{9}$.

w ustawie w tym zakresie dokonuje się przy zastosowaniu wskaźnika cen towarów i usług konsumpcyjnych ogłaszanego przez Prezesa Głównego Urzędu Statystycznego".

${ }^{5}$ Zgodnie z art. 5 u.g.n. sprzed nowelizacji "[w]aloryzacji kwot należnych z tytułów określonych w ustawie dokonuje się przy zastosowaniu wskaźników zmian cen nieruchomości ogłaszanych przez Prezesa Głównego Urzędu Statystycznego, w drodze obwieszczeń, w Dzienniku Urzędowym Rzeczypospolitej Polskiej «Monitor Polski»". Artykuł ten został zmieniony na mocy Ustawy z dnia 15 V 2015 r. o zmianie ustawy o gospodarce nieruchomościami (Dz.U. poz. 985).

${ }^{6}$ Wyrok TK z 21 VII 2011 r., sygn. K 23/08, OTK ZU 2011, nr 6/A, poz. 62.

${ }^{7}$ Ibidem. Do wyroku złożono dwa zdania odrębne, w tym M. Zubik, który rozwinął swoje stanowisko w artykule M. Zubik, Wielkości statystyczne w systemie prawa określonym przez Konstytucje z 1997 r., "Przegląd Sejmowy” 2011, nr 5, s. 9-22.

${ }^{8}$ Artykuł 227 u.g.n. został uchylony na mocy art. 1 pkt 3 Ustawy z dnia 15 V 2015 r. o zmianie ustawy o gospodarce nieruchomościami (Dz.U. poz. 985).

${ }_{9}$ Zob. wyrok TK z 9 III 2017 r., sygn. P 13/14, OTK ZU A/2017, poz. 14, w myśl którego: „[w] tej sytuacji jedynie dzięki przepisom ustawy o gospodarce nieruchomościami, które określają rodzaj docelowego (obecnie: art. 5 ust. 1 i 2 u.g.n.) oraz zastępczego (art. 227 u.g.n.; obecnie: art. 5 ust. 4 u.g.n. i art. 2 ustawy zmieniającej) wskaźnika waloryzacji, podczas przerachowywania kwot odszkodowań za wywłaszczone nieruchomości «organ administracji publicznej nie ma swobody dobierania wskaźników odzwierciedlających w sposób adekwatny zmiany w sile nabywczej pieniądza, na podstawie których dokonuje przeliczenia. Przepisy ustawy o gospodarce nieruchomościami wyrażają w tym zakresie wiążąco zamiar prawodawcy, nie pozostawiając możliwości oparcia rozstrzygnięcia o inne dane [...]» (wyrok WSA w Krakowie z 11 maja 2016 r., sygn. akt II SA/Kr 216/15, Lex nr 2056521). Art. 227 u.g.n. nie otwierał zatem organom administracyjnym drogi do podejmowania arbitralnych decyzji podczas ustalania 
W niniejszym opracowaniu nacisk położony jest przede wszystkim na przedstawienie mechanizmu dokonywania waloryzacji na przykładzie ustalonego i niewypłaconego odszkodowania za wywłaszczoną nieruchomość, bez uwzględniania oceny jego obiektywizmu przy wykorzystywaniu wskaźników cen towarów i usług konsumpcyjnych zamiast docelowych i bardziej sprawiedliwych, jednakże w przeważającej większości nieogłoszonych wskaźników zmian cen nieruchomości, które najrzetelniej odzwierciedliłyby zachodzące na rynku zmiany cen nieruchomości. Można wnioskować, że rola waloryzacji kwot przyznanego, lecz niewypłaconego odszkodowania sprowadza się do zapewnienia mu wynikającej ze standardów konstytucyjnych cechy „słuszności” 10 , która dopuszcza sytuacje, kiedy „odszkodowanie «słuszne» nie musi być pełne, tj. nie musi odpowiadać wartości rynkowej nieruchomości"11.

Omawiany mechanizm waloryzacji ustawa o gospodarce nieruchomościami wykorzystuje poza ujętym w opracowaniu przykładem wypłaty odszkodowania związanego z wywłaszczeniem nieruchomości (art. 132 ust. 1c, 3 i 3a) także w innych przypadkach, a mianowicie: $\mathrm{w}$ razie rozwiązania umowy użytkowania wieczystego przed upływem okresu ustalonego w umowie zwraca się zwaloryzowaną sumę opłat rocznych wniesionych z tego tytułu za niewykorzystany okres użytkowania wieczystego (art. 33 ust. 3a), w sytuacji zwrotu udzielonej bonifikaty od ceny nieruchomości (art. 68 ust. 2); w przypadku wykonania prawa odkupu partner prywatny lub spółka w ramach umowy o partnerstwie publiczno-prywatnym jest obowiązany przenieść na rzecz podmiotu publicznego własność nieruchomości za zwrotem zwaloryzowanej ceny (art. 68a ust. 3); w zakresie rozliczeń związanych ze zwrotem wywłaszczonych nieruchomości (art. 140 ust. 2 i 5, art. 217 ust. 2); przy ustalaniu wysokości opłaty adiacenckiej

wysokości kwot zwaloryzowanego odszkodowania. Przeciwnie, art. 227 u.g.n. odgrywał rolę instrumentu ograniczającego ich swobodę decyzyjną. Zobowiązywał organy administracyjne do korzystania z - istniejącego - obiektywnego kryterium przeliczenia kwot odszkodowań należnych z tytułu wywłaszczenia nieruchomości, jakim jest wskaźnik cen towarów i usług konsumpcyjnych. Po zmianie stanu normatywnego analogiczną funkcję pełnią art. 5 ust. 4 u.g.n. oraz art. 2 ustawy zmieniającej".

${ }^{10}$ Zgodnie z art. 21 ust. 2 Konstytucji Rzeczypospolitej Polskiej z dnia 2 IV 1997 r. (Dz.U. Nr 78, poz. 483 ze zm.) „[w]ywłaszczenie jest dopuszczalne jedynie wówczas, gdy jest dokonywane na cele publiczne i za słusznym odszkodowaniem".

${ }_{11}$ Postanowienie pełnego składu TK z 28 X 2015 r., sygn. P 6/13, OTK ZU 2015, nr 9/A, poz. 161, cz. II, pkt 5.2.3; wyrok TK z 9 III 2017 r., sygn. P 13/14, OTK ZU 2017, A, poz. 14. 
(art. 148 ust. 3); przy przeszacowaniu wartości katastralnych związanych z powszechną taksacją nieruchomości (art. 163 ust. 2); przy niezakończonych sprawach o stwierdzenie nabycia praw (art. 200 ust. 1 pkt 4 i ust. 2 pkt 2); w ramach roszczeń spółdzielni o ustanowienie użytkowania wieczystego na poczet ceny zalicza się zwaloryzowane opłaty poniesione z tytułu użytkowania budynków, innych urządzeń i lokali (art. 204 ust. 4).

Konieczność waloryzowania kwot wynika również z innych przepisów odrębnych, np.: w przypadku wykonania prawa pierwokupu zbycie mieszkania następuje po cenie podlegającej waloryzacji (art. 4 ust. 6 Ustawy z dnia 7 lipca 2005 r. o zmianie niektórych ustaw dotyczących nabywania własności nieruchomości ${ }^{12}$ ); w sytuacji, gdy nabywca lokalu jest zobowiązany do zwrotu zwaloryzowanej kwoty równej udzielonej bonifikacie (art. 40a ust. 5b Ustawy z dnia 28 września 1991 r. o lasach ${ }^{13}$ ); w przypadku waloryzacji wartości nieruchomości pozostawionych poza obecnymi granicami Rzeczypospolitej Polskiej oraz wartości nabytych praw (art. 14 ust. 3 Ustawy z dnia 8 lipca 2005 r. o realizacji prawa do rekompensaty z tytułu pozostawienia nieruchomości poza obecnymi granicami Rzeczypospolitej Polskiej ${ }^{14}$ ); w przypadku waloryzacji kwoty równej udzielonej bonifikacie przy przekształceniu prawa użytkowania wieczystego w prawo własności nieruchomości (art. 4 ust. 15 i 16 Ustawy z dnia 29 lipca 2005 r. o przekształceniu prawa użytkowania wieczystego w prawo własności nieruchomości ${ }^{15}$ ); w przypadku obowiązku zwrotu zwaloryzowanej zaliczki (art. 12 ust. 5b Ustawy z dnia 10 kwietnia 2003 r. o szczególnych zasadach przygotowania i realizacji inwestycji w zakresie dróg publicznych, dalej: „specustawa drogowa”16); w przypadku waloryzacji odszkodowania według zasad obowiązujących w przypadku zwrotu wywłaszczonych nieruchomości (art. 18 ust. 3 specustawy drogowej ${ }^{17}$, art. 9y ust. 3 Ustawy z dnia 28 marca 2003 r. o transporcie kolejowym $^{18}$, art. 23 ust. 3 Ustawy z dnia 24 kwietnia 2009 r. o inwestycjach $\mathrm{w}$ zakresie terminalu regazyfikacyjnego skroplonego gazu ziemnego

\footnotetext{
12 Dz.U. Nr 157, poz. 1315.

13 Tekst jedn. Dz.U. 2017, poz. 788 ze zm.

14 Tekst jedn. Dz.U. 2017, poz. 2097.

15 Tekst jedn. Dz.U. 2012, poz. 83 ze zm.

16 Tekst jedn. Dz.U. 2018, poz. 1474.

17 Tekst jedn. Dz.U. 2018, poz. 1474.

18 Tekst jedn. Dz.U. 2017, poz. 2117 ze zm.
} 
w Świnoujściu' ${ }^{19}$, art. 21 ust. 12 Ustawy z dnia 8 lipca 2010 r. o szczególnych zasadach przygotowania do realizacji inwestycji w zakresie budowli przeciwpowodziowych ${ }^{20}$ ).

\section{Mechanizm dokonywania waloryzacji przy zastosowaniu metody nawiązań łańcuchowych}

Wszystkie rozważania na temat szeroko pojętej waloryzacji skupiają się na pytaniu, jakie wskaźniki są dostępne, a jakie powinny być docelowo stosowane. Wskaźniki zmian cen nieruchomości są na razie, co do zasady, tylko teorią, która - miejmy nadzieję - w przyszłości zostanie urzeczywistniona. Natomiast praktyka wielu lat pokazuje, że jak na razie możliwe i jedyne wykorzystywane wskaźniki to wskaźniki cen towarów i usług konsumpcyjnych. I tu rodzi się pytanie, czy organy administracji publicznej wiedza, w jaki sposób prawidłowo dokonać waloryzacji odszkodowania, które zostało ustalone wiele lat wcześniej, ale nie zostało wypłacone. Oczywiście, takie wytyczne istnieją i można je pozyskać z GUS, doświadczenie i praktyka pokazują jednak, że nie wszystkie organy administracji publicznej z tej ścieżki korzystają; zjawisko to można zaobserwować zwłaszcza w organach pierwszej instancji. Nagminnie zdarza się, że organy, pozyskując z GUS gotowe wyliczenie waloryzacji w konkretnej sprawie, poprzestają na wskazaniu w uzasadnieniach decyzji wyłącznie zwaloryzowanej kwoty i powołaniu się na otrzymany dokument. Brak przy tym opisania szczegółowej metodologii waloryzacji z powołaniem się na: wykorzystane wskaźniki cen towarów i usług konsumpcyjnych, przedział czasowy objęty waloryzacja, przeprowadzone działania matematyczne. Taki zabieg jest dalece niewystarczający, sposób dokonywania waloryzacji nie powinien być bowiem i nie jest wiedzą zarezerwowaną wyłącznie dla biegłych z zakresu nauk ścisłych. Obowiązkiem organów jest omówienie w decyzji mechanizmu waloryzacji w sposób klarowny i zrozumiały dla strony.

Należy zauważyć, że sposób ustalania w decyzjach organów administracji publicznej wysokości odszkodowania budzi niejednokrotnie wątpliwości w odniesieniu do jego zgodności z ogólnymi zasadami prawa administracyjnego. Podkreślenia wymaga fakt, na który zwrócił uwagę Wojewódzki Sąd Administracyjny w Poznaniu w wyroku z 10 lipca 2008 r.,

\footnotetext{
${ }^{19}$ Tekst jedn. Dz.U. 2017, poz. 2302 ze zm.

${ }^{20}$ Tekst jedn. Dz.U. 2018, poz. 433 ze zm.
} 
a mianowicie, że „przepisy ustawy z dnia 21 sierpnia 1997 r. o gospodarce nieruchomościami [...] nie określają metody obliczania waloryzacji odszkodowania za wywłaszczoną nieruchomość. Wskazują jedynie, że wysokość odszkodowania ustalona w decyzji podlega waloryzacji na dzień jego zapłaty, a waloryzacji tej dokonuje organ, osoba lub jednostka organizacyjna zobowiązana do zapłaty odszkodowania (art. 132 ust. 3 u.g.n.)"21. Tym samym przepis ten, stanowiący podstawę dokonywania waloryzacji odszkodowania za wywłaszczenie, przy uwzględnieniu wytycznych określonych w ustawie o gospodarce nieruchomościami, stanowi lex specialis w stosunku do regulacji zawartej w art. $358^{1} \S 3$ Ustawy z dnia 23 kwietnia 1964 r. Kodeks cywilny ${ }^{22}$, w którym to unormowana jest sądowa waloryzacja, będąca wyjątkiem od zasady nominalizmu ${ }^{23}$.

Zgodnie z poglądem wyrażonym w orzecznictwie "[i]nstytucja waloryzacji odszkodowania za wywłaszczoną nieruchomość stanowi instrument ochrony finansowych interesów osób wywłaszczonych, mający zapewnić adekwatność pomiędzy wartością przyznanego odszkodowania w dacie jego ustalenia a wartością odszkodowania w momencie wypłaty. Należy szczególnie podkreślić, że waloryzacja nie służy weryfikacji wysokości ustalonego odszkodowania. Inaczej mówiąc, waloryzacja odszkodowania nie jest związana z szacowaniem nieruchomości i nie ma prowadzić do określenia jej wartości, to bowiem zostało już uczynione wcześniej w decyzji o wywłaszczeniu. Na etapie waloryzacji nie podlega już ocenie, czy ustalone w decyzji o wywłaszczeniu odszkodowanie istotnie odzwierciedlało wartość rynkową działki i czy odzwierciedla ją kwota wypłacana. Wielkość waloryzowanej kwoty podlegającej wypłacie jest pochodną ustalonego odszkodowania i zastosowanych współczynników służących waloryzacji" ${ }^{24}$.

Organy administracji publicznej niejednokrotnie, jak już zauważono, bez podania szczegółowej analizy odwzorowującej sposób dokonania waloryzacji kwoty odszkodowania, wskazują wyłącznie jej ostateczny wynik, tj. wysokość zwaloryzowanego odszkodowania, powołując się przy tym wyłącznie na treść art. 5 u.g.n. i zawarty w jego ust. 4 przepis

${ }^{21}$ Wyrok WSA w Poznaniu z 10 VII 2008 r., sygn. II SA/Po 110/08, http://orzeczenia. nsa.gov.pl/cbo/query (dostęp: 12 XI 2018).

${ }^{22}$ Tekst jedn. Dz.U. 2018, poz. 1025 ze zm.

${ }^{23}$ Zob. wyrok WSA w Warszawie z 25 I 2013 r., sygn. I Sa/Wa 2230/12, http://orzeczenia.nsa.gov.pl/cbo/query (dostęp: 12 XI 2018).

${ }^{24}$ Wyrok WSA w Gliwicach z 28 IX 2009 r., sygn. II SA/Gl 627/09, http://orzeczenia. nsa.gov.pl/cbo/query (dostęp: 12 XI 2018). 
o konieczności stosowania wskaźników cen towarów i usług konsumpcyjnych, gdyż Prezes GUS nie ogłosił dotychczas większości wskaźników zmian cen nieruchomości. Tym samym otrzymany wynik jest nieweryfikowalny i nie ma odpowiedniego uzasadnienia. Taka praktyka prowadzi do pozbawienia uprawnionych do otrzymania odszkodowania lub zobowiązanych do jego zwrotu możliwości przeanalizowania sposobu i prawidłowości ustalenia wysokości odszkodowania oraz dokonania odpowiedniej kontroli i weryfikacji w tym zakresie. Takie postępowanie stanowi naruszenie zawartej w art. 8 Ustawy z dnia 14 czerwca 1960 r. Kodeks postępowania administracyjnego ${ }^{25}$ zasady pogłębiania zaufania obywateli do organów państwa, a także zasady informowania stron (art. 9 k.p.a. oraz art. 107 § 3 k.p.a.), brak bowiem w uzasadnieniu decyzji przedstawienia przez organ administracji publicznej sposobu wyliczeń, w wyniku których uzyskano zwaloryzowaną kwotę odszkodowania, powoduje niemożność zweryfikowania jej zarówno przez stronę, jak i na dalszym etapie postępowania przez sąd ${ }^{26}$.

W orzecznictwie powszechnie przyjmuje się, że to na organie prowadzącym postępowanie w konkretnej sprawie spoczywa obowiązek szczegółowego i matematycznego wyjaśnienia sposobu wyliczania wysokości świadczenia, w szczególności zaś sposobu uzasadnienia jego wysokości ${ }^{27}$. Dotyczy to także dokonywania waloryzacji odszkodowania z zastosowaniem wskaźników cen towarów i usług konsumpcyjnych (wskaźnik inflacyjny) na podstawie poniżej wskazanego modelu postępowania.

Trzeba podkreślić, że wskaźniki cen towarów i usług konsumpcyjnych obliczane są z częstotliwością miesięczną od 1982 r. (nie są opracowywane wskaźniki na określony dzień). Dla lat wcześniejszych, tj. 1950-1981, dostępne są jedynie wskaźniki roczne, za lata kalendarzowe (rok poprzedni $=100)$. „Wskaźnik ten informuje, o ile (w \%) przeciętnie ceny towarów i usług konsumpcyjnych były wyższe bądź niższe w badanym okresie w porównaniu z okresem bazowym, co w uproszczeniu oznacza porównanie średniego poziomu cen w badanym okresie ze średnim poziomem cen okresu bazowego" ${ }^{\prime 28}$.

${ }^{25}$ Tekst jedn. Dz.U. 2018, poz. 2096, dalej „k.p.a.”.

${ }^{26}$ Zob. również rozważania zawarte w wyroku WSA w Warszawie z 20 I 2015 r., sygn. I SA/Wa 1992/14, http://orzeczenia.nsa.gov.pl/cbo/query (dostęp: 13 XI 2018).

${ }^{27}$ Por. wyrok WSA w Warszawie z 7 VI 2007 r., sygn. I SA/Wa 732/06, http://orzeczenia.nsa.gov.pl/cbo/query (dostęp: 13 XI 2018).

${ }^{28}$ Niepublikowane informacje pozyskane z Departamentu Informacji GUS w indywidualnych sprawach, które wykorzystano podczas przygotowywania artykułu, dalej "niepublikowane informacje z GUS". 
Wskaźnikami cen towarów i usług konsumpcyjnych ogłaszanymi przez Prezesa GUS, które stanowią podstawę dokonywania waloryzacji kwot odszkodowań, są w szczególności: roczne wskaźniki cen towarów i usług konsumpcyjnych od 1950 r., przy podstawie rok poprzedni $=100$ (zaprezentowane w tabeli 1), miesięczne wskaźniki cen towarów i usług konsumpcyjnych, przy podstawie rok poprzedni = 100, które do $2015 \mathrm{r}$. były udostępniane i obliczane przez GUS na zamówienie (zaprezentowane w tabeli 2), a także miesięczne wskaźniki cen towarów i usług konsumpcyjnych, przy podstawie miesiąc poprzedni $=100$ (zaprezentowane w tabeli 3).

Waloryzacja powinna być przeprowadzana zgodnie z przepisami prawa (które jednak nie regulują szczegółowo metody obliczeń stosowanej przy jej dokonywaniu) oraz z regułami matematycznymi i statystycznymi, przy wykorzystaniu ogłaszanych przez Prezesa GUS wyżej wskazanych wskaźników.

Idąc w ślad za orzecznictwem, należy wskazać, że "[w]aloryzacja zobowiązań (kwot i płatności) w gospodarce nieruchomościami to ustalenie wysokości istniejących zobowiązań pieniężnych przy zmianie systemu pieniężnego. [...] Innymi słowy waloryzacja dokonywana w trybie administracyjnym oznacza urealnienie już ustalonego odszkodowania. Takie stanowisko zostało potwierdzone w wyroku Naczelnego Sądu Administracyjnego w Warszawie z 7 maja 2002 r. sygn. akt I SA 2378/00"29.

„W przypadku, gdy okres objęty waloryzacją wykracza poza okresy, dla których wskaźniki cen towarów i usług konsumpcyjnych zostały opublikowane, wówczas do waloryzacji kwot GUS przyjął zasadę stosowania metody nawiązań łańcuchowych" ${ }^{\prime 30}$. Innymi słowy, jeśli zamierzamy zwaloryzować kwotę odszkodowania pochodzącą np. z maja 1982 r. na październik 2018 r., wówczas wyżej wymienioną kwotę należy przemnożyć wskaźnikiem cen towarów i usług konsumpcyjnych za okres października 2018 r. (przy podstawie maj 1982 r. = 100). Dla powyższego okresu (a także dla analogicznych przykładów) nie obliczono i nie opublikowano jednego wskaźnika cen towarów i usług konsumpcyjnych, dlatego też $w$ tego typu przypadkach do obliczenia wskaźnika cen znajduje zastosowanie wyżej wskazana metoda nawiązań łańcuchowych. Metoda ta polega na mnożeniu pierwszego wskaźnika w łańcuchu wykorzystywanym do nawiązań przez kolejny

${ }^{29}$ Wyrok WSA w Poznaniu z 15 IX 2010 r., sygn. IV SA/Po 406/10, http://orzeczenia. nsa.gov.pl/cbo/query (dostęp: 14 XI 2018).

${ }^{30}$ Niepublikowane informacje z GUS. 
wskaźnik i podzieleniu przez 100. Tak otrzymany wskaźnik zaokraglany jest do jednego miejsca po przecinku i mnożony przez kolejny wskaźnik, analogicznie jak w poprzednim kroku. Kolejne operacje mnożenia, dzielenia przez 100 i zaokrąglania należy powtarzać aż do ostatniego wskaźnika w łańcuchu nawiązań ${ }^{31}$.

WSA w Krakowie w wyroku z 20 maja 2016 r. stanął na stanowisku, że "[p]owyższa metoda pozwala [...] na obliczenie stopnia zmiany cen w danym okresie, dla którego nie obliczono jednego wskaźnika, w związku z tym zachodzi potrzeba uwzględnienia szeregu wskaźników odzwierciedlających zmiany cen w krótszych okresach składających się na okres badany, w efekcie czego uzyskuje się wartość zwaloryzowaną w całym okresie, za który dokonuje się waloryzacji"32.

Kwoty odszkodowania pochodzące z lat 1950-1981, a także z okresu późniejszego, w przypadku gdy nie jest ustalony konkretny miesiąc, którego dotycza, waloryzowane są z wykorzystaniem kolejnych wskaźników rocznych (przy podstawie rok poprzedni $=100$ ) oraz wskaźnika miesięcznego (przy podstawie rok poprzedni $=100$ ). Pierwszym wskaźnikiem w łańcuchu wykorzystywanym do nawiązań powinien być wskaźnik mający w podstawie okres, z którego pochodzi kwota do waloryzacji, a ostatnim - wskaźnik dotyczący miesiąca, na który ustalana jest zwaloryzowana kwota ${ }^{33}$.

\section{Analiza sposobu dokonywania waloryzacji kwoty odszkodowania (ustalonego i niewypłaconego) przy zastosowaniu metody nawiązań łańcuchowych z wykorzystaniem wskaźników rocznych i wskaźników miesięcznych}

Jako ilustrację zaprezentowanych wywodów można wskazać następujący przykład ${ }^{34}$ : kwota do waloryzacji (6000 „starych” złotych) pochodzi

\footnotetext{
${ }^{31}$ Ibidem.

${ }^{32}$ Wyrok WSA w Krakowie z 20 V 2016 r., sygn. II SA/Kr 319/16, http://orzeczenia. nsa.gov.pl/cbo/query (dostęp: 15 XI 2018).

${ }^{33}$ Niepublikowane informacje z GUS.

${ }^{34}$ Przykład przedstawiony na podstawie indywidualnej sprawy w przedmiocie waloryzacji kwoty odszkodowania za wywłaszczoną nieruchomość, którą autorka artykułu prowadziła jako pracownik Wielkopolskiego Urzędu Wojewódzkiego w Poznaniu, zakończonej decyzją Wojewody Wielkopolskiego z 12 XI 2007 r., nr SN.III-8.77242-36/07, utrzymaną w mocy wyrokiem WSA w Poznaniu z 10 VII 2008 r., sygn. II SA/Po 110/08,
} 
z 1962 r. (tj. zapłata miała nastąpić w 1962 r.) i należy ustalić jej zwaloryzowaną wartość w maju $2007 \mathrm{r}$. W tym przypadku powyższa kwota powinna zostać zwaloryzowana z wykorzystaniem kolejnych rocznych wskaźników cen towarów i usług konsumpcyjnych za lata 1963-2006 ( przy podstawie rok poprzedni $=100$ ) oraz wskaźnika miesięcznego za maj 2007 r. (przy podstawie rok poprzedni $(2006)=100)$. Tym samym pierwszym wykorzystanym wskaźnikiem rocznym jest wskaźnik za $1963 \mathrm{r}$. (przy podstawie rok poprzedni $(1962)=100)$, ostatnim zaś - wskaźnik miesięczny za maj 2007 r. (przy podstawie rok poprzedni $(2006)=100)$.

Tabela 1. Roczne wskaźniki cen towarów i usług konsumpcyjnych od 1950 r.

\begin{tabular}{|c|c|c|c|c|c|}
\hline Rok & $\begin{array}{c}\text { Wskaźnik cen przy } \\
\text { podstawie } \\
\text { rok poprzedni }=100\end{array}$ & Rok & $\begin{array}{l}\text { Wskaźnik cen przy } \\
\text { podstawie } \\
\text { rok poprzedni }=100\end{array}$ & Rok & $\begin{array}{l}\text { Wskaźnik cen przy } \\
\text { podstawie } \\
\text { rok poprzedni }=100\end{array}$ \\
\hline 1950 & 107,5 & 1973 & 102,8 & 1996 & 119,9 \\
\hline 1951 & 109,6 & 1974 & 107,1 & 1997 & 114,9 \\
\hline 1952 & 114,4 & 1975 & 103,0 & 1998 & 111,8 \\
\hline 1953 & 141,9 & 1976 & 104,4 & 1999 & 107,3 \\
\hline 1954 & 93,7 & 1977 & 104,9 & 2000 & 110,1 \\
\hline 1955 & 97,6 & 1978 & 108,1 & 2001 & 105,5 \\
\hline 1956 & 99,0 & 1979 & 107,0 & 2002 & 101,9 \\
\hline 1957 & 105,4 & 1980 & 109,4 & 2003 & 100,8 \\
\hline 1958 & 102,7 & 1981 & 121,2 & 2004 & 103,5 \\
\hline 1959 & 101,1 & 1982 & 200,8 & 2005 & 102,1 \\
\hline 1960 & 101,8 & 1983 & 122,1 & 2006 & 101,0 \\
\hline 1961 & 100,7 & 1984 & 115,0 & 2007 & 102,5 \\
\hline 1962 & 102,5 & 1985 & 115,1 & 2008 & 104,2 \\
\hline 1963 & 100,8 & 1986 & 117,7 & 2009 & 103,5 \\
\hline 1964 & 101,2 & \begin{tabular}{|l|}
1987 \\
\end{tabular} & 125,2 & 2010 & 102,6 \\
\hline 1965 & 100,9 & 1988 & 160,2 & 2011 & 104,3 \\
\hline 1966 & 101,2 & 1989 & 351,1 & 2012 & 103,7 \\
\hline 1967 & 101,5 & 1990 & 685,8 & 2013 & 100,9 \\
\hline 1968 & 101,6 & 1991 & 170,3 & 2014 & 100,0 \\
\hline 1969 & 101,4 & 1992 & 143,0 & 2015 & 99,1 \\
\hline 1970 & 101,1 & 1993 & 135,3 & 2016 & 99,4 \\
\hline 1971 & 99,9 & 1994 & 132,2 & 2017 & 102,0 \\
\hline 1972 & 100,0 & 1995 & 127,8 & & \\
\hline
\end{tabular}

Źródło: Główny Urząd Statystyczny, http:/ / stat.gov.pl/obszary-tematyczne/ceny-handel/wskazniki-cen/ wskazniki-cen-towarow-i-uslug-konsumpcyjnych-pot-inflacja-/roczne-wskazniki-cen-towarow-i-uslug-konsumpcyjnych/ (dostęp: 14 XI 2018).

który został utrzymany w mocy wyrokiem NSA z 16 IX 2009 r., sygn. I OSK 1272/08, http://orzeczenia.nsa.gov.pl/cbo/query (dostęp: 15 XI 2018). 
Tabela 2. Miesięczne wskaźniki cen towarów i usług konsumpcyjnych przy podstawie rok poprzedni $=100$ (do 2015 r. miesięczne wskaźniki cen towarów i usług konsumpcyjnych przy podstawie rok poprzedni $=100$ były udostępniane i obliczane przez GUS na zamówienie)

\begin{tabular}{|c|c|c|c|c|c|c|c|c|c|c|c|c|c|}
\hline & \multirow{2}{*}{ ok } & \multicolumn{12}{|c|}{ Miesiąc } \\
\hline & & I & 11 & 11 & V & V & VI & VII & & IX & $X$ & XI & XIII \\
\hline \multirow{4}{*}{ 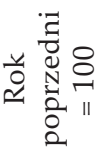 } & 2018 & 01,3 & 101,1 & 101,0 & 101,5 & 101,7 & 101,8 & 101,6 & 101,6 & 101,8 & 102,2 & & \\
\hline & 2017 & 101,4 & 101,7 & 101,6 & 101,9 & 102,0 & 101,8 & 101,6 & 101,5 & 101,9 & 102,4 & 102,9 & 103,1 \\
\hline & 2016 & 99,1 & 98 & 99,1 & 99,3 & 99,5 & 99,7 & 99,4 & 99 & 99,1 & 9,6 & 99,7 & 100,4 \\
\hline & 2015 & 98,9 & 98,8 & 99,0 & 99,4 & 99,4 & 99,5 & 99,4 & 99,0 & 98,8 & 98,9 & 98,8 & 98,7 \\
\hline
\end{tabular}

Źródło: Główny Urząd Statystyczny, http://stat.gov.pl/obszary-tematyczne/ceny-handel/wskaznikicen/wskazniki-cen-towarow-i-uslug-konsumpcyjnych-pot-inflacja-/miesieczne-wskazniki-cen-towarow-iuslug-konsumpcyjnych-od-1982-roku/ (dostęp: 14 XI 2018).

Obliczenia przeprowadza się metodą nawiązań łańcuchowych, zaokrąglając wynik do jednego miejsca po przecinku po wykonaniu każdej operacji mnożenia ${ }^{35}$. Powyższa uwaga, co należy podkreślić, ma istotne znaczenie, doświadczenie pokazuje bowiem, że wytyczna ta ulega pewnym modyfikacjom dokonywanym przez organy przeprowadzające waloryzację, a mianowicie niezmiernie często stosowane jest uproszczenie przyjmujące postać "skrótu” obliczeniowego, tj. zamiast zaokrąglania wyniku do jednego miejsca po przecinku po każdym działaniu mnożenia następujących po sobie wskaźników (i dzielenia przez 100), oblicza się iloczyn wszystkich wymaganych rocznych wskaźników cen towarów i usług konsumpcyjnych (w powyższym przykładzie byłby to iloczyn za lata 1963-2006) oraz wskaźnika miesięcznego (w omawianym przykładzie za maj 2007 r.).

Akceptowalne wydaje się jednak stanowisko, że jest to nieznaczne uchybienie, gdyż różnica w końcowych wynikach jest zazwyczaj marginalna. $\mathrm{W}$ przypadku omawianego powyżej przykładu prawidłowo obliczony wskaźnik cen towarów i usług konsumpcyjnych w maju 2007 r. w stosunku do 1962 r. wyniósł (w \%) 464 754,5, podczas gdy wskaźnik uzyskany przy zastosowaniu „skrótu” obliczeniowego wyniósł (w \%) 464597,9 .

Kwota 6000 „starych" złotych zwaloryzowana prawidłowo obliczonym wskaźnikiem w maju 2007 r. (tj. iloczyn tej kwoty i prawidłowo uzyskanego wskaźnika) wyniosła przy uwzględnieniu denominacji (tj. wynik podzielony przez 10000 w myśl Ustawy z dnia 7 lipca 1994 r.

${ }^{35}$ Niepublikowane informacje z GUS. 
o denominacji złotego ${ }^{36}$ ) 2788,53 zł. Natomiast przy użyciu wskaźnika uzyskanego w wyniku zastosowania "skrótu" obliczeniowego kwota po waloryzacji (i denominacji) wyniosła 2787,59 zł. Różnica w końcowych wynikach wyniosła więc $0,94 \mathrm{zł}$. W kontekście powyższego można stwierdzić, że wynik obliczeń uzyskany w drodze "skrótu” mieści się w granicach "błędu statystycznego". Co więcej, należy również wskazać, że organ, wydając decyzję, powinien uwzględniać ostatni przed wydaniem decyzji ogłoszony, opublikowany przez Prezesa GUS wskaźnik cen towarów i usług konsumpcyjnych. Warto zauważyć, iż wskaźniki miesięczne publikowane są na stronie internetowej GUS 15 dnia każdego miesiąca następującego po miesiącu, za który podawany jest wskaźnik ${ }^{37}$.

Jeżeli kwota do waloryzacji pochodzi z konkretnego miesiąca po 1981 r., wówczas waloryzacji dokonujemy przy zastosowaniu miesięcznych wskaźników cen towarów i usług konsumpcyjnych (bez konieczności posiłkowania się wskaźnikami rocznymi), mających jednak $\mathrm{w}$ podstawie miesiac poprzedni $=100$, a nie rok poprzedni $=$ 100, jak to miało miejsce w opisanym powyżej przykładzie. Przy założeniu, że kwota do waloryzacji pochodzi z kwietnia 1996 r. i należy ustalić jej zwaloryzowaną wartość w grudniu 2003 r., powinno się tę kwotę zwaloryzować z wykorzystaniem kolejnych miesięcznych wskaźników cen towarów i usług konsumpcyjnych w okresie maj 1996 - grudzień 2003 (przy podstawie miesiąc poprzedni = 100). Innymi słowy, pierwszym wykorzystanym wskaźnikiem miesięcznym jest wskaźnik za maj 1996 r. (przy podstawie kwiecień 1996 = 100), ostatnim zaś zastosowanym wskaźnikiem miesięcznym jest wskaźnik za grudzień 2003 r. (przy podstawie listopad $2003=100)$. Obliczenia matematyczne opierają się na analogicznych regułach jak w przykładzie szczegółowo objaśnionym powyżej, tym samym nie ma potrzeby prowadzenia wnikliwych rozważań na ten temat. Można tylko zasygnalizować i jednocześnie podkreślić, że przy wykorzystywaniu w łańcuchu nawiązań wyłącznie wskaźników miesięcznych, ich podstawę powinien stanowić miesiąc poprzedni $=100$, a nie rok poprzedni $=100$.

${ }^{36}$ Dz.U. Nr 84, poz. 386 ze zm.

${ }^{37}$ Główny Urząd Statystyczny, http://stat.gov.pl/obszary-tematyczne/ceny-handel/ wskazniki-cen/wskazniki-cen-towarow-i-uslug-konsumpcyjnych-pot-inflacja-/miesie czne-wskazniki-cen-towarow-i-uslug-konsumpcyjnych-od-1982-roku/(dostęp: 16 XI 2018). 
Tabela 3. Miesięczne wskaźniki cen towarów i usług konsumpcyjnych przy podstawie miesiąc poprzedni $=100$

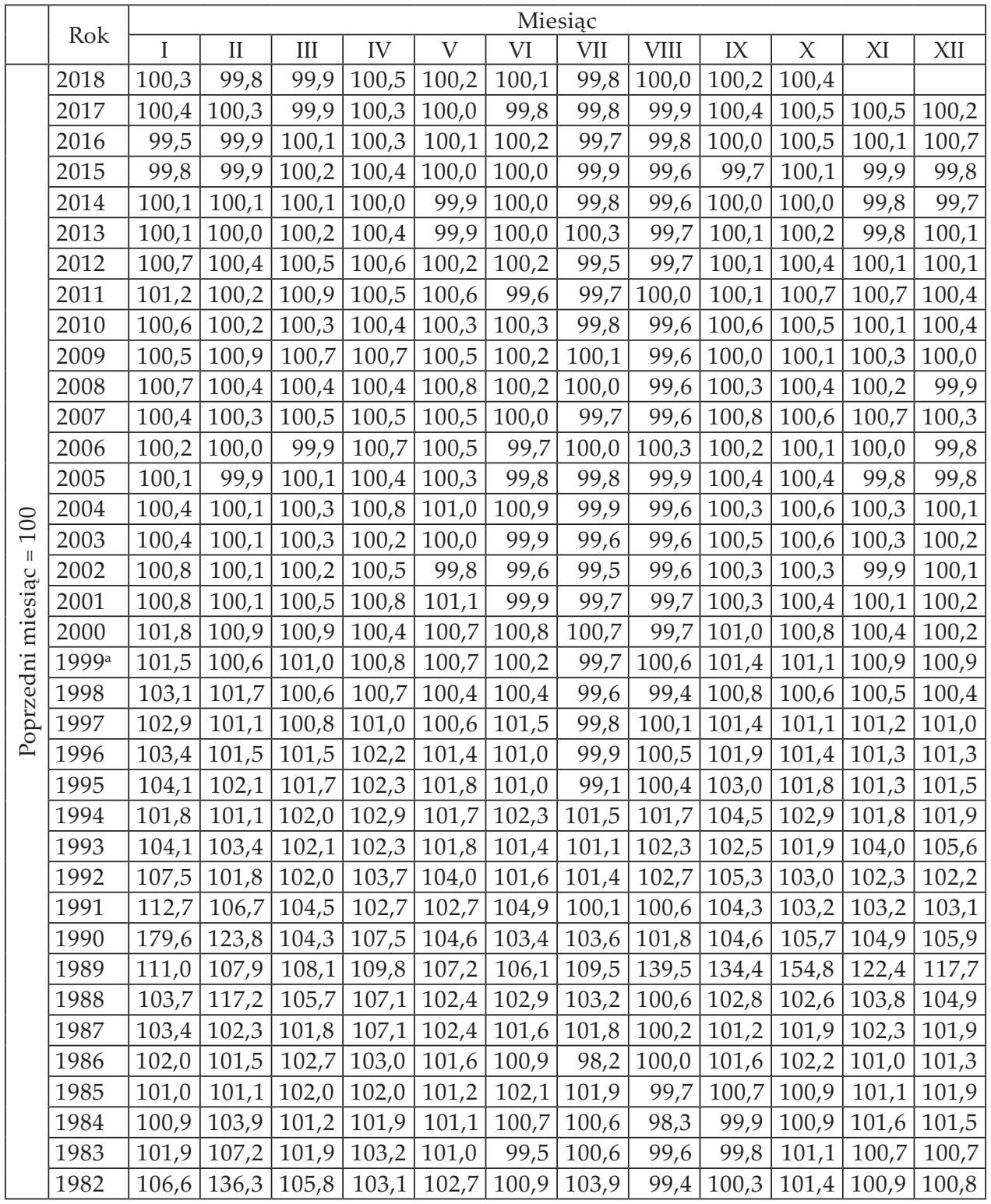

a Od stycznia 1999 r. wskaźniki cen towarów i usług konsumpcyjnych obliczane są według klasyfikacji COICOP (klasyfikacja spożycia indywidualnego według celu).

Źródło: Główny Urząd Statystyczny, http:/ / stat.gov.pl/obszary-tematyczne/ceny-handel/wskazniki-cen/ wskazniki-cen-towarow-i-uslug-konsumpcyjnych-pot-inflacja-/miesieczne-wskazniki-cen-towarow-i-uslugkonsumpcyjnych-od-1982-roku/ (dostęp: 14 XI 2018). 


\section{Najczęstsze błędy popełniane przez organy administracji publicznej podczas obliczania waloryzacji kwot odszkodowania, które nie mieszczą się w ramach wyżej opisanych zasad stosowanych przez GUS}

Jedną z częstych nieprawidłowości jest opisane już wcześniej ułatwienie polegające na "skrótowym" obliczaniu końcowego wskaźnika cen towarów i usług konsumpcyjnych. Organy administracji nie stosują mianowicie odpowiednich matematycznych reguł zaokrągleń po każdej operacji mnożenia poszczególnych wskaźników cen towarów i usług konsumpcyjnych, można jednak przyjąć, że wynik otrzymanego - wskutek zastosowanego uproszczenia - iloczynu wszystkich wykorzystanych w danym przypadku wskaźników mieści się w dopuszczalnym „błędzie statystycznym".

Spotykanym niejednokrotnie uchybieniem jest również waloryzowanie kwoty pochodzącej z okresu po roku 1981 - w przypadku której można ustalić konkretny miesiąc, kiedy miała nastąpić wypłata odszkodowania - przy wykorzystaniu wskaźników rocznych (przy podstawie rok poprzedni $=100$ ) zamiast wskaźników miesięcznych (przy podstawie miesiąc poprzedni $=100$ ).

Niezgodne z wytycznymi stosowanymi przez GUS jest waloryzowanie np. kwoty z 1975 r. w stosunku do sierpnia 2014 r. wskaźnikami rocznymi do $1982 \mathrm{r}$. (przy podstawie rok poprzedni $=100$ ), a następnie wskaźnikami miesięcznymi aż do sierpnia 2014 r. (przy podstawie miesiąc poprzedni $=100$ ).

Ponadto spotyka się niepoprawne stosowanie w metodzie nawiązań łańcuchowych wskaźników mających naprzemiennie w podstawie miesiąc lub rok poprzedni = 100 (na marginesie należy podkreślić, że jest to oczywiście dopuszczalne, jednak przy odpowiednich założeniach zgodnych z regułami matematycznymi rządzącymi omawianą metodą i użyciu właściwych wskaźników cen). Przykładowo, nieprawidłowe waloryzowanie kwoty z maja 1982 r. do listopada 2016 r.: w pierwszym etapie wskaźnikami miesięcznymi za okres od czerwca do grudnia $1982 \mathrm{r}$. ( przy podstawie miesiąc poprzedni $=100$ ), w drugim etapie wskaźnikami rocznymi za okres od 1983 r. do 2015 r. (przy podstawie rok poprzedni = 100), a w trzecim etapie znów wskaźnikami miesięcznymi za okres od stycznia do listopada $2016 \mathrm{r}$. (przy podstawie miesiąc poprzedni $=100$ ). W tym schemacie wyłania się jeszcze jedna znacząca wada, a mianowicie podwójna waloryzacja okresu od maja do grudnia 1982 r. (w pierwszym etapie obliczeń przy wykorzystaniu miesięcznych wskaźników (grudzień 
1982 r./przy podstawie maj 1982 r. = 100) i w drugim etapie przy wykorzystaniu rocznych wskaźników (styczeń-grudzień 2016 r./przy podstawie styczeń-grudzień 1982 r.). Przy czym wyżej wymieniony drugi etap, stosujący roczne wskaźniki, bezpodstawnie ujmuje w waloryzacji okres od stycznia do kwietnia 1982 r., waloryzowana kwota pochodzi bowiem dopiero z maja 1982 r. Tak przeprowadzone obliczenia dyskwalifikują otrzymany wskaźnik cen towarów i usług konsumpcyjnych jako konieczny do dokonania prawidłowej waloryzacji. W tym przypadku najtrafniejsze i wskazane byłoby oparcie metody nawiązań łańcuchowych na wskaźnikach miesięcznych, co jest rozwiązaniem pozbawionym ryzyka błędu, który może być konsekwencją niewłaściwego z regułami wykorzystania do waloryzacji naprzemiennie wskaźników miesięcznych i rocznych (co wymagałoby od organów administracji pogłębionej wiedzy w przedmiotowej materii) ${ }^{38}$.

Kolejnym uchybieniem, z którym można się spotkać w praktyce wydawania decyzji administracyjnych, jest stosowanie podwójnej waloryzacji kwoty odszkodowania. Wynika to z błędnej wykładni art. 132 ust. 3 u.g.n..$^{39}$ przyjmującej, że obejmuje on swoją dyspozycją decyzję o waloryzacji odszkodowania, a nie decyzję o ustaleniu odszkodowania. W piśmiennictwie prezentowany jest pogląd, iż "waloryzacja odszkodowania następuje zawsze od momentu jego ustalenia (daty wydania decyzji wywłaszczeniowej) do dnia zapłaty odszkodowania" ${ }^{\prime \prime}$.

\section{Różne poglądy na temat zasądzania odsetek za okres objęty waloryzacją}

W myśl pierwszego stanowiska waloryzacja ustalonego i niewypłaconego odszkodowania oznacza niedopuszczalność zasądzenia odsetek za okres objęty waloryzacją. W opisanych okolicznościach prawo do

\footnotetext{
${ }^{38}$ Niepublikowane informacje z GUS; zob. też wyrok WSA w Krakowie z 28 VII 2015 r., sygn. II SA/Kr 634/15, http://orzeczenia.nsa.gov.pl/cbo/query (dostęp: 17 XI 2018); wyrok WSA w Krakowie z 20 V 2016 r., sygn. II SA/Kr 319/16, http://orzeczenia.nsa. gov.pl/cbo/query (dostęp: 17 XI 2018).

${ }^{39}$ Zgodnie z art. 132 ust. 3 u.g.n. „[w]ysokość odszkodowania ustalona w decyzji podlega waloryzacji na dzień jego zapłaty. Waloryzacji dokonuje organ, osoba lub jednostka organizacyjna zobowiązana do zapłaty odszkodowania.

${ }^{40}$ M. Szalewska, Wywłaszczenie nieruchomości, Torun 2005, s. 286, cyt. za: wyrok NSA z 1 III 2011 r., sygn. I OSK 621/10, http://orzeczenia.nsa.gov.pl/cbo/query (dostęp: 17 XI 2018).
} 
odsetek może powstać w przypadku opóźnienia lub zwłoki w wypłacie świadczenia już zwaloryzowanego ${ }^{41}$. Należy zauważyć, że skoro waloryzacja jest urealnieniem ustalonej, ale niewypłaconej kwoty odszkodowania, to nie jest wymagane naliczenie dodatkowo odsetek za przedział czasu objęty waloryzacją.

Przeciwnicy powyższych twierdzeń prezentują bardziej przekonujące stanowisko, zgodnie z którym waloryzacja i skutki zwłoki lub opóźnienia w zapłacie odszkodowania to dwa odrębne zagadnienia. Skoro w dyspozycji art. 132 ust. 2 u.g.n. uregulowano kwestię skutków zwłoki lub opóźnienia w wypłacie odszkodowania, wskazując, że stosuje się w tym zakresie odpowiednio przepisy Kodeksu cywilnego, to nie przedstawiając obszernego dyskursu na ten temat, należy jedynie zasygnalizować, powołując się na stanowisko wyrażone w wyroku Naczelnego Sądu Administracyjnego z 7 maja 2002 r., iż "odsetki należą się wierzycielowi w każdym wypadku opóźnienia niejako automatycznie i stanowią dla dłużnika sankcję za sam fakt niespełnienia świadczenia w terminie, chociażby dłużnik nie popadł w zwłokę"42. Tym samym odsetki powinny być liczone od dnia, w którym miała nastąić wypłata odszkodowania, do dnia, w którym wypłata ta de facto nastąiłiła ${ }^{43}$. Wykluczone jest zatem liczenie odsetek od zwaloryzowanej kwoty, gdyż to nie z zapłatą tej kwoty dłużnik się opóźnił ${ }^{44}$.

\section{Podsumowanie}

Za cel niniejszego artykułu przyjęto stworzenie kompilacji pozwalającej na ujęcie w jednym miejscu uniwersalnych zasad i informacji niezbędnych do prawidłowego wykonania waloryzacji ustalonego i niewypłaconego odszkodowania za wywłaszczoną nieruchomość, a także waloryzacji odszkodowania wypłaconego, ale zwracanego w ramach rozliczeń związanych ze zwrotem wywłaszczonej nieruchomości. Należy się

${ }^{41}$ Wyrok NSA z 30 V 2012 r., sygn. I OSK 788/11, w związku z wyrokiem WSA w Poznaniu z 23 II 2011 r., sygn. IV SA/Po 1032/10, http://orzeczenia.nsa.gov.pl/cbo/query (dostęp: 17 XI 2018).

${ }^{42}$ Wyrok NSA z 7 V 2002 r., sygn. I SA 2378/00, LEX nr 81740.

${ }^{43}$ Wyrok WSA w Warszawie z 8 I 2016 r., sygn. IV SA/Wa 2912/15; wyrok WSA w Łodzi z 27 VIII 2013 r., sygn. II SA/Ld 419/13, http://orzeczenia.nsa.gov.pl/cbo/query (dostęp: 17 XI 2018).

${ }^{44}$ Wyrok WSA w Warszawie z 20 I 2015 r., sygn. I SA/Wa 1992/14, http://orzeczenia. nsa.gov.pl/cbo/query (dostęp: 17 XI 2018). 
zgodzić ze stwierdzeniem wyrażonym w wyroku WSA w Krakowie z 20 maja 2016 r., że „przepisy prawa nie regulują szczegółowo sposobu obliczeń, jednakże istotne jest to, aby organ przyjmując pewne założenia nie wypaczył wyniku waloryzacji" ${ }^{\prime 4}$. Celem dodatkowym było stworzenie kompendium wiedzy dla wszystkich zainteresowanych przedmiotową tematyką waloryzacji oraz dla organów administracji publicznej i sądów administracyjnych, które niejednolicie podchodzą do powyższego zagadnienia, co przekłada się następnie na jakość i prawidłowość podejmowanych rozstrzygnięć w indywidualnych sprawach. Dlatego jako wniosek de lege ferenda należałoby postulować wprowadzenie ujednoliconego, doprecyzowanego i ogólnie dostępnego wzoru prawidłowej metodologii i mechanizmu dokonywania waloryzacji - kwot odszkodowania ustalonego, ale niewypłaconego, bądź koniecznego do zwrotu jako rozliczenia związanego ze zwrotem wywłaszczonej nieruchomości - tak aby można było dokonać jednoznacznej weryfikacji poprawności otrzymanej w wyniku waloryzacji kwoty odszkodowania, nie dopuszczając przy tym różnych form interpretacji.

\section{AN ANALYSIS AND PRACTICAL PRESENTATION OF THE METHODOLOGY AND MECHANISM OF VALORISATION ON THE EXAMPLE OF AN ESTABLISHED AND OUTSTANDING COMPENSATION FOR AN EXPROPRIATED PROPERTY}

\section{S u m mary}

The aim of this article was to create a compilation that would allow for the inclusion in one place of universal principles necessary for the proper implementation of valorisation of the established and unpaid compensation for the expropriated property. In recent years, there has been a worrying phenomenon of arbitrariness and inconsistency in addressing the issue of the compensation valorisation mechanism in question, which is associated with the inadequate practical and mathematical implementation of the valorisation in question by public administration bodies. This may be due not so much to a lack of understanding of the subject as to insufficient practical knowledge of how to make mathematical calculations correctly. It should be remembered that an incorrect adjustment affects the final result, which is the amount of compensation. Thus, this error may imply undue payment of compensation, both on the part of the state bodies and on the part of persons entitled to the return of expropriated real estate, who are obliged to return the valorised compensation as part of their settlements. The subject of this study

${ }^{45}$ Wyrok WSA w Krakowie z 20 V 2016 r., sygn. II SA/Kr 319/16, http://orzeczenia. nsa.gov.pl/cbo/query (dostęp: 17 XI 2018). 
was exclusively the methodology and mechanism for adjusting the amounts of compensation for expropriated property, without taking into account the assessment of its objectivity when using consumer price indices instead of target indicators, but in the vast majority of unannounced indices of changes in property prices, that would most accurately reflect changes in property prices on the market. An implication of de lege ferenda demands unification and clarification of the formula of the correct mechanism for making indexing amounts of established and unpaid compensation for expropriated real estate so that an unambiguous verification of the correctness of the final result can be made.

Keywords: valorisation of compensation for expropriated property - adjoining sequential method - established and outstanding compensation - price indices of consumer goods and services - indicators of changes in property prices 